\title{
MOENCHIA ERECTA (L.) G. Gaertn., B. Mey \& Scherb. AND CATAPODIUM MARINUM (L.) C.E. Hubb. TWO NEW SPECIES IN THE FLORA OF THE REPUBLIC OF MACEDONIA
}

\author{
Vlado Matevski ${ }^{1,2}$, Andraž Čarni ${ }^{1,3}$ \\ ${ }^{1}$ Macedonian Academy of Sciences and Arts, Skopje, Republic of Macedonia \\ ${ }^{2}$ Faculty of Natural Sciences and Mathematics, Ss. Cyril and Methodius University, \\ Skopje, Republic of Macedonia \\ ${ }^{3}$ Institute of Biology, Research Center of the Slovenian Academy of Sciences and Arts, \\ Ljubljana, Slovenia \\ e-mail: vlado.matevski@yahoo.com, carni@zrc-sazu.si
}

\begin{abstract}
The paper deals with the two new species for the flora of the Republic of Macedonia - Moenchia erecta (L.) G. Gaertn., B. Mey \& Scherb. and Catapodium marinum (L.) C.E. Hubb. and their distribution on the territory of the Republic of Macedonia.
\end{abstract}

Key words: Moenchia erecta; Catapodium marinum; flora; distribution; Republic of Macedonia

\section{INTRODUCTION}

The floristic and vegetation researches performed intensively in the Republic of Macedonia in the last period have led to new knowledge about the presence of new, hitherto unknown species for the territory. During our research of early spring thermophilic vegetation of the alliance Romulion (Helianthemetalia, Helianthemetea), which develops in the southern and southeastern parts of the discussed territory (Dojran, Strumica, Radoviš) and scrub vegetation in the zone of pseudomaquis (Paliuretalia, Crataego-Prunetea) (Gevgelija, Valandovo, Bogdanci, Dojran, Strumica, Demir Kapija) [1] we found two new species in the flora of the Republic of Macedonia - Moenchia erecta (Caryophyllaceae) and Catapodium marinum (Poaceae).

\section{MATERIAL AND METHODS}

The floristic investigation has been carried out according to the standard methods. For the pur- poses of determining the plant species, the most important floristic works concerning the flora of Europe [2, 3], Balkan Peninsula [4-7], Republic of Macedonia [8] and other regional floras, as well as some special papers and databases [9] dealing with taxonomy, nomenclature and chorology of the taxa studied were used. The herbarium material is deposed in the Herbarium of the Institute of Biology, Faculty of Natural Sciences and Mathematics in Skopje (MKNH).

\section{RESULTS AND DISCUSSION}

\section{Moenchia erecta (L.) G. Gaertn., B. Mey \& Scherb.}

Moenchia erecta is a small annual plant with ascending basal branches. Flowers are tetramerous with 4 stamens and cylindrical capsule, usually slightly exceeding the sepal. It is widespread in most of Europe (mainly in the Mediterranean region, Atlantic Europe - West, Central and South 
Europe, North, North-West Africa and the Middle East [3,9], and secondarily in North America [10] (Figure 1).

It is a rare plant species in the Balkan Peninsula, only known from few localities in the territory of Greece [7], Bulgaria [6], Croatia [11] and Slovenia [12].

In Republic of Macedonia it was first discovered in the southeastern parts (Strumica-Novo Selo), near the border with Bulgaria (Figure 2). It develops in habitats with typical early spring thermophilic vegetation that belongs to the sub-Mediterranean ass. Lago-Poetum bulbosae, alliance Romulion (Helianthemetalia, Helianthemetea). In the elaborated territory, such vegetation is dominated by: Aira elegantissima Schur, Alyssum desertorum Stapf, Achillea coarctata Poir., Galium divaricatum Pourr. ex Lam., Hypochoeris cretensis (L.) Bory et Chaub., Hypochoeris glabra L., Linaria pelisseriana (L.) Mill., Lotus angustissimus L., Myosotis ramosissima Rochel, Ornithopus compressus L., Plantago bel- lardii All., Poa bulbosa L., Psilurus incurvus (Gouan) Schinz et Thell., Romulea bulbocodium (L.) Sebast. et Mauri, Scleranthus verticillatus Tausch, Trifolium campestre Schreb., Trifolium scabrum L., Tuberaria guttata (L.) Fourr., Vulpia ciliata Dumort and others.

In the northern and northeastern parts of Greece (Thassos, Kavala, Myrtofito, Askos, Nea Peramos), M. erecta appears in the population of the Mediterranean community - ass. Romuleo graecaePoetum bulbosae [13]. It can be found on grazed places also elsewhere in the Mediterranean basin $[14,15]$ and it belongs to an element of Mediterranean heavily grazed dry grasslands [16].

Distribution in Republic of Macedonia:

Mk: Strumica-Novo Selo, on silicate bedrock 41.43231; 22.90296, 361 m., 16.5.2007 (leg. et det V. Matevski et A. Čarni) (MKNH)

Mk: Strumica-Novo Selo, on silicate bedrock 41.42425, 22.89463, 514 m., 16.5.2007 (leg. et det V. Matevski et A. Čarni) (MKNH)

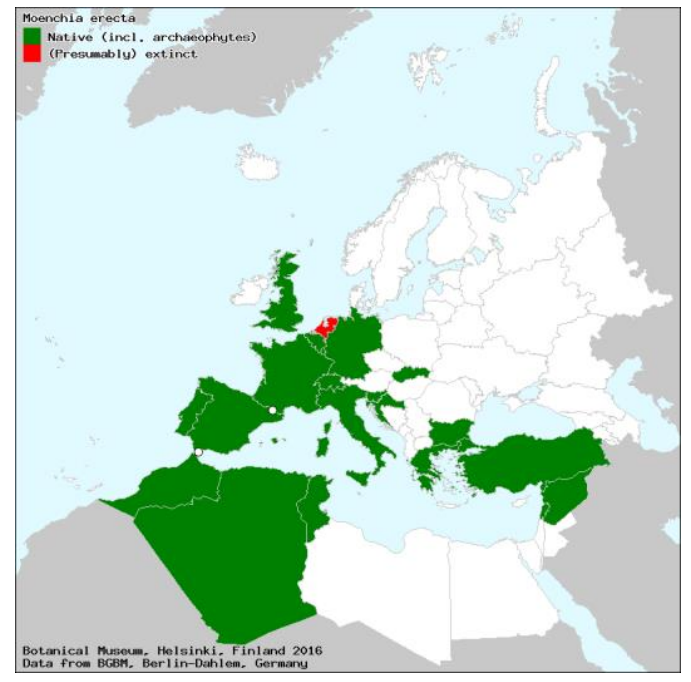

Figure 1. Map of distribution of Moenchia erecta (according the Euro+Med Plant Base)

\section{Catapodium marinum (L.) C.E. Hubb.}

Syn.: Desmazeria marina (L.) Druce, Catapodium loliaceum (Hudson) Link., Desmazeria loliacea (Hudson) Nyman; Catapodium pauciflorum (Merino) Brullo, Sclerochloa loliacea (Hudson) Woods.

The distribution range of Catapodium marinum covers dry open habitats near the sea in the South and West coasts of Europe, northwards to $59^{\circ}$ $\mathrm{N}$ in Scotland (Orkney), North Africa and Middle

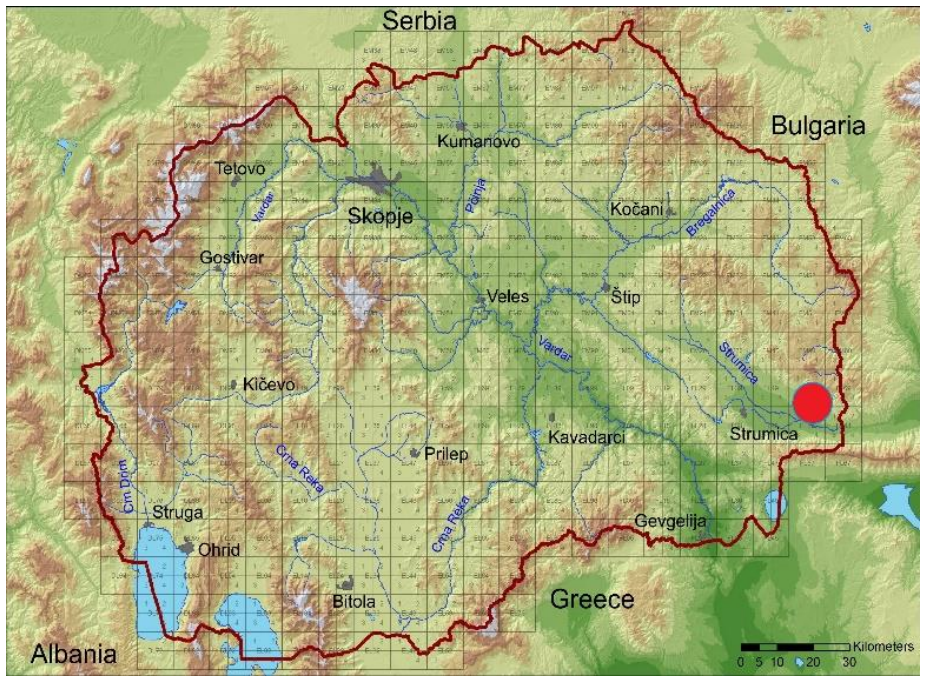

Figure 2. Distribution of Moenchia erecta in the Republic of Macedonia

East [2, 9] (Figure 3). This species can be found along the Adriatic sea [17-19] and also elsewhere along the coast of Balkan Peninsula [20]. Most often this species appears on coastal habitats, close to the sea: sand dunes, and also in trampled habitats [21].

According to the available literature data this species has not been known for the Republic of Macedonia. It was discovered in surrounding of the city of Strumica (Figure 4), in the zone of shrubby vegetation (pseudomaquis) dominated by the following woody and shrubby species - Quercus coc- 
cifera L., Carpinus orientalis Mill., Crataegus monogyna Jacq., Ligustrum vulgare L., Lonicera etrusca Santi, Pyrus amygdaliformis Vill., Quercus pubescens Willd., Rosa sempervirens L. and others. In the herb (ground) layer of the pseudomaquis along with Catapodium marinum dominate Alyssum minutum Schltdl. ex DC, Arabidopsis thaliana (L.) Heynh., Aristolochia pallida Willd., Asterolinon linum stellatum (L.) Duby, Cardamine hirsuta L., Carex distachya Desf., Cephalaria ambrosioides (Sibth. et Sm.) Roem. et Schult., Crepis pulchra L., Cystopteris fragilis (L.) Bernh., Dianthus pinifolius Sm., Draba muralis L., Filago gallica L., Lathyrus sphaericus Retz., Lupinus angustifolius L., Luzula forsteri (Sm.) DC., Medicago minima (L.) L., Scandix australis L., Sedum cepaea L., Silene italica (L.) Pers., Stipa bromoides (L.) Doerfl., Thymus sibthorpii Benth., Torilis arvensis (Huds.) Link, Trifolium angustifolium L., Trifolium arvense L., Trifolium dalmaticum Vis., Valerianella turgida (Steven)
Betcke, Veronica arvensis L., Vicia hirsuta (L.) Gray, Vicia lathyroides L., Vicia villosa Roth, Viola kitaibeliana Schult., Vulpia myuros (L.) C.C.Gmel. and others.

Ecological conditions in the reported locality were somehow different from that, reported by other authors. This area has been overpopulated already from the ancient times, there have been migrations of people (e.g. recent of "Syrian refugees") and the transhumance has been practiced for a long time [22]. So the species can move easily from the neighbouring coast in the pseudomaquis in the southern part of the Republic of Macedonia. But it is a question whether its occurrence here is stable or may be ephemeral.

Distribution in the Republic of Macedonia:

Mk: Strumica-Carevi Kuli, on silicate bedrock, 41.434333, 22.622861; SW, 518 m, 15.05.2011 (leg. et det V. Matevski et A. Čarni) (MKNH)

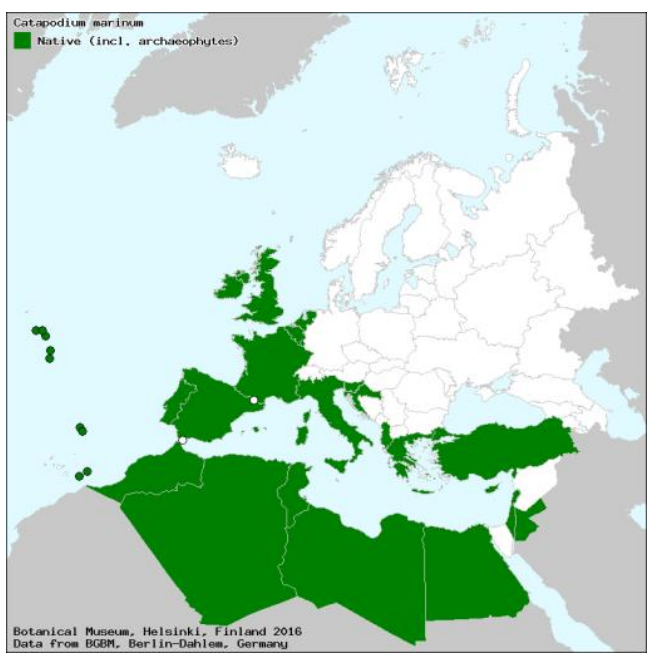

Figure 3. Map of distribution of Catapodium marinum (according the Euro+Med Plant Base)

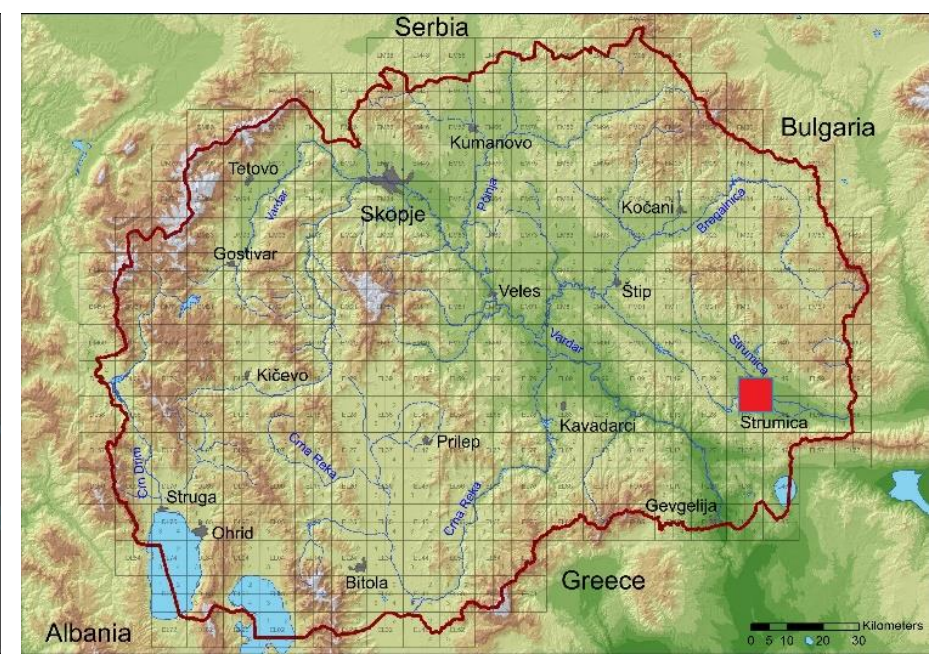

Figure 4. Distribution of Catapodium marinum in the Republic of Macedonia

\section{CONCLUSION}

The work deals with the newly established populations of two new species of the flora of the Republic of Macedonia and their distribution on its territory - Moenchia erecta (L.) P. Gaertn. (Strumica-Novo Selo) and Catapodium marinum (L.) C. E. Hubb (Strumica-Carevi Kuli).

These and many other thermophilous species with Mediterranean distribution pattern (e.g. Anthemis auriculata Boiss., Chaenorhinum rubrifolium (DC.) Fourr., Convolvulus elegantissimus Mill., Corynephorus divaricatus (Pourr.) Breistr. Dittrichia graveolens (L.) Greuter, Dittrichia viscosa
(L.) Greuter, Galium setaceum Lam., Helianthemum aegyptiacum (L.) Mill., Hymenocarpos circinatus (L.) Savi, Silene galica L., Tolpis umbellata Bertol, Urtica pilulifera L. and others) [23-31) that have been found in the Republic of Macedonia in the near past show the influence of global warming [32] on flora and vegetation in the region. We can consider plant species as a good indicator of changing climate. In this way we have to monitor the appearance of those species and predict the climatic changes that are foreseen.

Acknowledgement. The authors acknowledge the financial support from the Slovenian Research Agency (P1-0236) and the Ministry of Education and Science of the Republic of Macedonia 


\section{REFERENCES}

[1] L. Mucina, H. Bültmann, K. Dierssen, J.-Paul Theurillat, T. Raus, A. Čarni, K. Šumberová, W. Willner, J. Dengler, R. Gavilán García, M. Chytrý, M. Hájek, R. Di Pietro, J. Pallas, F. J. A. Daniëls, E. Bergmeier, A. Santos Guerra, N. Ermakov, M. Valachovič, J. H. J. Schaminée, T. Lysenko, Y. P. Dudukh, S. Pignatti, J. S. Rodwell, J. Capelo, H. E. Weber, A. Solomeshch, P. Dimopoulos, C. Aguiar, S.M. Hennekens, L. Tichý, Vegetation of Europe: Hierarchical floristic classification system of vascular plant, bryophyte, lichen, and algal communities. Applied Vegetation Science, 19 (2016), pp. 3-264.

[2] A. C. Stace, Desmazeria Dumort. (incl. Catapodium Link, Scleropoa Griseb.) in Tutin T. G. et al. (eds), Flora Europaea, 5 (1980) p. 158, Cambridge.

[3] A. R. Clapham, Moenchia Ehrh. in Tutin T. G. et al. (eds) Flora Europaea 1 (1993), pp. 175-176, Cambridge.

[4] A. Hayek, Prodromus Florae peninsulae Balcanicae, I. Repert. Spec. Nov. Regni Veg., Beih. 30 (1924-1927), Dahlem bei Berlin.

[5] A. Hayek, Prodromus Florae peninsulae Balcanicae, III. Repert. Spec.Nov. Regni Veg., Beih. 30 (1933), Dahlem bei Berlin.

[6] I. Asenov, Moenchia Ehrh. in Jordanov (eds) Flora Reipublicae Popularis Bulgaricae, 3 (1966) pp. 359-365, Acad. Scient. Bulgaricae, Serdicae.

[7] A. Strid, Moenchia Ehrh. in Strid A., Tan, K. (ed.) Flora Hellenica, 1 (1997), pp. 214-215, Koeltz Scientific Books, D-6240 Königstein/Federal Republic of Germany.

[8] K. Micevski, Moenchia Ehrh. in (eds) Flora na Republika Makedonija. MANU, Skopje, 1 (2) (1993) pp. 272-274.

[9] Euro+Med Plant Base - http://ww2.bgbm.org/Euro PlusMed/query.asp

[10] D. M. Ketzner Crepis pulchra (Asteraceae) and Moenchia erecta (Caryophyllaceae) in Illinois. Transactions of the Illinois State Academy of Science, 89 (1-2) (1996), pp 21-23.

[11] T. Nikolić, Flora croatica. Index Florae Croaticae. Pars 1. Natura croatica, 3 (2) (1994), pp. 1-116.

[12] B. Vreš, Moenchia Ehrh. in Martinčič, A. et al., Mala Flora Slovenije; ključ za določanje praprotnic in semenk. 4. dopolnjena in spremenjena izd., 1 natis, (2007), Ljubljana:Tehniška založba Slovenije.

[13] A. Čarni, V. Matevski, U. Šilic, R. Ćušterevska, Early spring ephemeral therophytic nonnitrophilous grasslands as a habitat of various species of Romulea in the southern Balkans. Acta Bot. Croat., 73 (1) (2014), pp. 107-129.

[14] E. Cano, A. G. Fuentes, A. Cano-Ortiz, Diversidad de pastizales de Poa bulbosa en el sur de la Península Ibérica. Pastos, 33 (2) (2013), pp. 253-265.
[15] I. Odriozola, G. García-Baquero, M. J. Fortin, N. A. Laskurain, A. Aldezabal, Grazing exclusion unleashes competitive plant responses in Iberian Atlantic mountain grasslands. Applied Vegetation Science, 20 (1) (2017), pp. 50-61.

[16] A. M. Janssen, J. S. Rodwell, M. García Criado, S. Gubbay, T. Haynes, A. Nieto, N. Sanders, F. Landucci, J. Loidi, A. Ssysmak, T. Tahvanainen, M. Valderrabano, A. Acosta, M. Aronsson, G. Arts, F. Attorre, E. Bergmeier, R.-J. Bijlsma, F. Bioret, C. Biţă-Nicolae, I. Biurrun, M. Calix, J. Capelo, A. Čarni, M. Chytrý, J. Dengler, P. Dimopoulus, F. Essl, H. Gardfjell, D. Gigante, G. Giusso del Galdo, M. Hájek, F. Jansen, J. Jansen, J. Kapfer, A. Mickolajczak, J. A. Molina, Z. Molnár, D. Paternoster, A. Piernik, B. Poulin, B. Renaux, J. H. J. Schaminée, K. Šumberová, H. Toivonen, T. Tonteri, I. Tsiripidis, R. Tzonev, M. Valachovič, European Red List of Habitats - Part 2. Terrestrial and freshwater habitats. Publication office of EU, (2016), Luxembourg.

[17] T. Nikolić, Flora croatica. Index Florae Croaticae. Pars 2. Natura croatica, 6 (1) (2000), pp. 1-232.

[18] E. Baliousis, Flora in vegetacija otoka Kalamos (Ionsko morje, Grčija). Hacquetia, 14 (2) (2015), pp. 307-318.

[19] U. Šilc, A. Mullaj, A. Alegro, A. Ibraliu, Z. Dajić Stevanović, M. Luković, D. Stešević, Sand dune vegetation along the eastern Adriatic coast. Phytocoenologia, 46 (4) (2016), pp. 339-355.

[20] T. Constantinidis, The flora of the Kastellorizo island group (East Aegean Islands, Greece): New records and comments. Flora Mediterranea, 23 (2013), pp. 69-86.

[21] A. Čarni, N. Jogan, Vegetation of thermophilic trampled habitats in the bay of Kvarner. Natura Croatica, 7 (1) (1998), pp. 45-58.

[22] R. Krauß, E. Marinova, H. De Brue, B. Weninger, The rapid spread of early farming from the Aegean into the Balkans via the Sub-Mediterranean-Aegean Vegetation Zone. Quaternary International 30 (2017), pp. 1-18.

[23] V. Matevski, Novi podatci o flori Republike Makedonije. $7^{\text {th }}$ Symposium on Flora of Southeastern Serbia and Neighbouring Regions, Proceeding, (2002), pp. 9-13 Dimitrovgrad.

[24] В. Матевски, Нови податоци за флората на Република Македонија. Год. зб. Биол. 55/56 (2002-2003), pp. 1-10, Скопје.

[25] V. Matevski, Ditrichia viscosa (L.) Greuter and Rudbeckia laciniata L. In: Greuter, W. Raab-Straube, E. von (ed.), Euro+Med Notule,3. [Notulae ad floram euro-mediterraneam pertinents 25]. Willdenowia, 37 (2007), pp. 139-189, Berlin-Dahlem

[26] V. Matevski, M. Kostadinovski, Hymenocarpus circinatus (L.) Savi, a new species of the flora of Re- 
public of Macedonia. Zbornik radova V Simpozijuma o flori jugoist. Srbije, (1997), pp. 41-44, Niš.

[27] В. Матевски, М. Костадиновски, Прилог за флората на Република Македонија III, Год. зб. Биол., 52 (1999), pp. 102-108, Скопје.

[28] V. Matevski, A. Čarni, M. Kostadinovski, Novi podatci o flori Republike Makedonije. $8^{\text {th }}$ Symposium on Flora of South-eastern Serbia and Neighbouring Regions, Proceeding, (2005), pp. 25-28, Niš.

[29] В. Матевски, К. Мицевски, М. Костадиновски, Прилог за флората на Република Македонија. Год. зб. Биол., 45 (1992), стр. 167-174, Скопје.

[30] В. Матевски, Ж. Сековски, М. Костадиновски, Ретки и слабо познати растенија во флората на
Република Македонија, Год. зб. Биол., 46 (1993), стр. 115-118, Скопје.

[31] В. Матевски, Ж. Сековски, М. Костадиновски, Прилог за хорологијата на Sideritis lanata (L.) Boiss. и Sideritis raeseri Boiss. \& Heldr. во флората на Република Македонија. Год.зб. Биол., 48 (1994), стр. 43-48, Скопје.

[32] A. Čarni, V. Matevski, Impact of Climate Change on Mountain Flora and Vegetation in the Republic of Macedonia (Central Part of the Balkan Peninsula). In: Öztürk, M., Hakeem, K. R., FaridahHanum, I., Efe, R. (ed.), Climate change impacts on high-altitude ecosystems, (2015), pp. 189-213, Spinger, Switzerland.

\section{MOENCHIA ERECTA (L.) G. GAERTN., B. MEY \& SCHERB. И CATAPODIUM MARINUM (L.) С.Е. НUВВ. ДВА НОВИ ВИДА ЗА ФЛОРАТА НА РЕПУБЛИКА МАКЕДОНИЈА Владо Матевски ${ }^{1,2}$, Андраж Чарни ${ }^{1,3}$}

\footnotetext{
${ }^{1}$ Македонска академија на науките и уметностите, Скопје, Република Македонија ${ }^{2}$ Природно-математички факултет, Универзитет „Св. Кирил и Методиј“, Скопје, Република Македонија

${ }^{3}$ Научно истражувачки центар на Словенечката академија на науките и уметностите, Љубљана, Словенија
}

\footnotetext{
Трудот се однесува на распространувањето на два нови, досега недоволно познати видови за флората на Република Македонија - Moenchia erecta (L.) G. Gaertn., B. Mey \& Scherb. (Струмица-Ново Село) и Catapodium marinum (L.) C.E. Нubb. (Струмица-Цареви Кули). Македонија

Клучни зборови: Moenchia erecta; Catapodium marinum; флора; распространување; Република
} 
